\title{
Interaction of Pre-implantation Embryo with Endometrial Cells
}

\author{
Parvati Sharma* \\ Department of Zoology, CBLU, Bhiwani, India \\ *Corresponding Author: Parvati Sharma, Department of Zoology, CBLU, Bhiwani, India.
}

Received: May 20, 2019; Published: June 14, 2019

DOI: 10.31080/ASAG.2019.03.0530

The fertility of dairy animals has declined worldwide and this change is surprising given the importance of good fertility to the dairy industry. It is estimated that approximately $50 \%$ of the potential profitability from genetic selection for milk production is lost due to a reduction in fertility [1]. The reduction in fertility can be explained by managemental changes within the dairy industry and also negative genetic correlations between milk production and reproduction. There are four mechanisms that reduce fertility in lactating animals that are (i) failure to cycle and display estrus (an ovulatory and behavioral an estrus), (ii) suboptimal and irregular estrous cyclicity, (iii) abnormal pre-implantation embryo development and, (iv) uterine/placental incompetence. Uterine disease is associated with lower conception rate, increased intervals from calving to first service or conception, and more dairy animals culled for failure to conceive (Azawi., et al. 2008). Pregnancy losses are thought to occur primarily during the pregnancy recognition/ pre-implantation period, making studies of endometrial gene expression critical to further understanding of pregnancy establishment, recognition and maintenance within the animal reproductive cycle. The cause of fertilization failure can also lie with the bull and the technique and timing of insemination when using artificial insemination. Infectious agents like bacteria (Streptococcus spp., Enteriobacteriacee spp., Proteus spp., Staphylococcus spp., Leptospira and Bacillus Licheiniformis) can also cause of the embryonic losses in dairy animals $[2,3]$.

It has been observed that the successful implantation of the blastocyst depends on adequate interactions between the embryo and the uterus. Implantation means the first intimate relationship between maternal tissues and developing foetus. For proper implantation and the subsequent placentation formation many physiological events needs to be complete sequentially. After conception in the oviduct, a fertilized ovum passes through a number of developmental stages that begins with its cleavage and form morula. Morulacells converted into blastocyst and inner cell mass (ICM) during a period of compaction of its cells.
At the time of implantation, increased concentrations of ovarian steroid hormones initiated a complex signaling cascade that stimulates the differentiation of endometrial stromal cells to decidual cells, preparing the uterus to lodge the embryo. Studies in humans and in other mammals have shown that cytokines and growth factors are produced by the pre-implantation embryo and cells of the reproductive tract. The actions of interleukin-1, leukemia inhibitory factor, epidermal growth factor, heparin-binding epidermal growth factor, and vascular endothelial growth factor, and on the network of their interactions leading to early embryo development, pre-implantatory endometrial changes, embryo implantation and trophoblast differentiation. The use of embryo co-culture systems using "helper" cells is one such approach that may afford benefit to certain animals, specifically those with history of poor embryo quality or repeated implantation failure. The initial studies of embryo co-culture took place in animals. In 1965, Cole and Paul demonstrated improved blastulation rates with culture of mouse embryos on a HeLa cell line. The use of such helper cell lines then gained popularity during the 1970s in the field of domestic animal biotechnology. Later on, several types of somatic cells were used to support mammalian pre-implantation embryo development in vitro [4]. This approach was again refined using trophoblastic vesicles and oviduct epithelial cells in ruminant embryo culture [58], and soon found applications in clinical practice [9]. Since then, embryo somatic co-culture has been applied to a broad spectrum of species, including cattle [5], rabbit [10], guinea pig [11], hamster [12], mink [13], cat [14], monkey [15], horse [16], goat [17], mouse [18], buffalo [19], camel [20], pig [21], rat [22], dog [23], and of course, human [24].

It has been suggested that the low rate of pregnancy result from implantation failure and therefore, the process and mechanism of normal implantation must be elucidated in order to increase the rate of successful pregnancy. 


\section{Bibliography}

1. Agarwal S K., et al. "Reproductive disorders and their management in cattle and buffaloes: a review". Indian Journal of Animal Sciences 75.7 (2005): 858-873.

2. Campanile G., et al. "Embryonic mortality in buffaloes synchronized and mated by AI during the seasonal decline in reproductive function". Theriogenology 63.8 (2005): 23342340 .

3. Campanile G., et al. "Strategies to reduce embryonic mortality in buffalo cows". Italian Journal of Animal Science 6.2 (2007): 680-683.

4. Biggers JD., et al. "Development of mouseembryos in organ cultures of fallopian tubes on a chemicallydefined medium". Nature 194 (1962): 747-749.

5. Camous S., et al. "Cleavage beyondthe block stage and survival after transfer of early bovineembryos cultured with trophoblastic vesicles". Journal of reproduction and fertility 72.2 (1984): 479-485.

6. Gandolfi F and Moor RM. "Stimulation of early embryonic developmentin the sheep by co-culture with oviduct epithelial cells". Journal of reproduction and fertility 81.1 (1987): 23-28.

7. RexroadJr CE and Powell AM. "Co-culture of ovine ova withoviductal cells in medium 199". Journal of Animal Science 66.4 (1988): 947-953.

8. Eyestone WH and First NL. "Co-culture of early cattle embryos tothe blastocyst stage with oviducal tissue or in conditionedmedium". Journal of reproduction and fertility 85.2 (1989): 715-720.

9. Bongso A., et al. "Co-cultures: their relevance toassisted reproduction". Human Reproduction 5.8 (1990): 893-900.

10. Carney EW., et al. "Co-culture of rabbit onecellembryos with rabbit oviduct epithelial cells". In Vitro Cellular and Developmental Biology 26.6 (1990): 629-635.

11. Leckie CM and Poyser NL. "Effect of guinea-pig conceptus and itssecretions on endometrial prostaglandin output". Prostaglandins, Leukotrienes Essential Fatty Acids 47 (1992): 269278.

12. Noda Y., et al. "Analysis of oviduct-derived embryonic growth stimulatoractivity". International journal of fertility and menopausal studies 38.1 (1993): 57-64.

13. Moreau GM., et al. "Development of immortalized endometrial epithelialand stromal cell lines from the mink (Mustelavison) uterusand their effects on the survival in vitro of mink blastocysts inobligate diapause". Biology of Reproduction 53.3 (1995): 511-518.
14. Swanson WF., et al. "Persistence of the developmentalblock of in vitro fertilized domestic cat embryos totemporal variations in culture conditions". Molecular Reproduction and Development 43.3 (1996): 298-305.

15. Lanzendorf SE., et al. "The effect of coculture on the postfertilizationdevelopment of in vitro-matured monkey oocytes". Fertility and Sterility 65.2 (1996): 420-425.

16. Guignot F., et al. "Preliminary observations in in vitro development of equine embryo after ICSI". Reproduction Nutrition Development 38.6 (1998): 653-663.

17. Izquierdo D., et al. "Effect of culturemedia on embryo development from prepubertal goat IVM-IVFoocytes". Theriogenology 52.5 (1999): 847-861.

18. Lee KF., et al. "Early developing embryos affect the gene expression patterns in the mouse oviduct." Biochemical and Biophysical Research Communications 292.2 (2002): 564-570.

19. Nandi S., et al. "Developmental competence and post-thaw survivability of buffalo embryos produced in vitro: effect of growth factors inoocyte maturation medium and of embryo culture system". Theriogenology 60.9 (2003): 1621-1631.

20. KhatirH.,etal."Productionofdromedary(Camelusdromedarius) embryos by IVM and IVF and coculturewith oviductal or granulosa cells". Theriogenology 62.7 (2004): 1175-1185.

21. Allen RL and Wright Jr RW. "In vitro development of porcineembryos in coculture with endometrial cell monolayers orculture supernatants". Journal of Animal Science 59.6 (1984): 1657-1661.

22. Tiwari R., et al. "Implantation in vitro: cocultureof rat blastocyst and epithelial cell vesicles". Cell and Tissue Research 315.2 (2004): 271-277.

23. Hatoya S., et al. "Effect of co-culturing with embryonic fibroblastson IVM, IVF and IVC of canine oocytes". Theriogenology 66.5 (2006): 1083-1090.

24. Bongso A., et al. "Human embryonic behavior in a sequential human oviduct-endometrial coculture system". Fertility and Sterility 61.5 (1994): 976-978.

\section{Volume 3 Issue 7 July 2019 \\ C) All rights are reserved by Parvati Sharma.}

